\author{
JOLANTA ZALĘCZNY \\ ORCID: 0000-0003-0615-410X
}

Akademia Finansów i Biznesu Vistula, Filia im. Aleksandra Gieysztora w Pułtusku

\title{
Maria Mazurkówna ze Lwowa sekretarka GTOZ, opiekunka przyrody i miłośniczka historii
}

Hasło ochrony przyrody wybrzmiało z nową mocą na początku XX wieku. W działalność taką zaangażowało się wiele osób, które znalazły dla siebie miejsce w funkcjonujących już od XIX wieku stowarzyszeniach. Jednym z nich było, działające od roku 1876, Galicyjskie Towarzystwo Ochrony Zwierząt. Spośród jego aktywnych działaczy — obok Józefa Białyni Chołodeckiego warto wymienić Marię Mazurkównę. Współcześnie nazwano by ją ekologiem, a właściwie ekolożką, aktywistką na rzecz ochrony zasobów naturalnych. Zapoznanie się z jej działalnością i poglądami utwierdza w przekonaniu, że troska o przyrodę oraz popularyzowanie haseł ekologicznych nie jest niczym nowym, a postawy proekologiczne były równie jak dziś popularne w dwudziestoleciu międzywojennym. Inne były oczywiście formy i możliwości oddziaływania na opinię publiczną. Drugim obszarem działalności Mazurkówny było upowszechnianie wiedzy historycznej, przybliżanie wydarzeń i postaci z przeszłości, czyli kreowanie postaw patriotycznych i kształtowanie świadomości historycznej ówczesnego społeczeństwa Lwowa, Galicji, a także szerzej mieszkańców ziem polskich.

Celem opracowania jest przedstawienie dorobku Marii Mazurkówny, osoby nieznanej, a przecież godnej zapamiętania. Niewiele o niej wiadomo, dlatego ważne jest połączenie w całość wiadomości pochodzących z różnych źródeł, $\mathrm{w}$ tym $\mathrm{z}$ artykułów prasowych oraz materiałów archiwalnych z Kolekcji Leopolis w zbiorach Muzeum Niepodległości w Warszawie. Zespół nazwany archiwaliami Marii Mazurkówny zawiera 31 pozycji pochodzących z lat 1911-1921. Są to głównie rękopisy wierszy oraz kopie materiałów drukowanych w prasie. 
Maria Mazurkówna urodziła się we Lwowie w roku 1877 w rodzinie Daniela Mazurka (zmarłego w sędziwym wieku w 1913 roku, pochowanego na cmentarzu Łyczakowskim ${ }^{1}$ ). Była poetką, autorką artykułów o tematyce przyrodniczej i historycznej. Wyjechała ze Lwowa w roku 1945, zamieszkała w Łodzi, tam też zmarła w roku 1966. W zbiorach Muzeum Niepodległości zachowały się dwie fotografie $\mathrm{z}$ okresu powojennego ${ }^{2}$, ale nie ma żadnych wiadomości na temat tego okresu jej życia.

Jednym z elementów zbioru jest legitymacja członkowska Związku Zawodowego Literatów Polskich we Lwowie. Wystawiona na nazwisko Maria Mazurkówna (Lwów, ulica Na Skałce 1) na rok 1921/1922 z numerem 5, a potem przedłużana na kolejne lata (do roku 1925$)^{3}$, jest widomym znakiem jej zainteresowań literackich. Potwierdzają to zgromadzone teksty autorstwa Mazurkówny, które oddają wrażliwość, ukazują zauroczenie przyrodą i zaangażowanie na rzecz jej ochrony. Dowodzą też różnorodnych zainteresowań. Poza pięknem przyrody fascynowała ją bowiem historia i sprawy codzienne Lwowa. Ta zróżnicowana tematyka każe więc analizować dorobek Mazurkówny na różnych płaszczyznach.

O jej tekstach pisano w 1908 roku na łamach „Miesięcznik GTOZ”: „Kreślone barwnie artykuły p. Marii Mazurkównej stwierdzają dokładną obserwację stosunków, subtelne czucie i współczucie dla cierpień ogółu stworzeń"4 .

Mazurkówna była autorką licznych wierszy adresowanych do odbiorców w różnym wieku, opracowań o tematyce historycznej oraz przyrodniczej. Wśród nich warto wymienić broszurę Mituj przyrodę ${ }^{5}$. Należy temu opracowaniu poświęcić nieco uwagi, bo odegrało istotną rolę w krzewieniu idei ochrony przyrody. Wydano je w 1911 roku staraniem Polskiego Towarzystwa Pedagogicznego $\mathrm{w}$ nakładzie kilku tysięcy egzemplarzy ${ }^{6}$. Wydrukowano w drukarni Józefa Chęcińskiego we Lwowie. GTOZ nabyło 500 egzemplarzy i prowadziło dystrybucję broszury. Można ją było kupić u ówczesnego prezesa Adolfa Mossila, sprzedawali ją też członkowie, między innymi Fanny Dittner i Ferdynand Waltoś. W broszurze znalazły się wiersze (Szepty wiosenne, Zawsze wierny, Motyl, W ów cudny czas, Mewy, Refleksje, Ja i ptaszę, Kolibry, Odlatujacym ptakom, Jesienia, Pożegnanie, W lesie, Nadchodzi zima, W noc

1 „Miesięcznik Galicyjskiego Towarzystwa Ochrony Zwierząt” (dalej jako: „Miesięcznik GTOZ”) 1913, nr 5-6, s. 24.

2 Muzeum Niepodległości (dalej: MN), F-11890, F-11891. Pierwsza z fotografii została wykonana w Lodzi, w Foto Cuchrowski przy ulicy Daszyńskiego 24.

3 MN, Zespół A 2. Kolekcja Leopolis, sygn. 38 (dalej: A.2/38), k. 1-4.

4 Zamknięcie roku 1908, „Miesięcznik GTOZ” 1908, nr 12, s. 178.

5 Ibidem, s. 48-99.

6 Z piśmiennictwa, „Rodzina i Szkoła” 1911, nr 11, 12, 13, 14, s. 195. Szczegóły dotyczące wydania broszury omawiano na posiedzeniu Wydziału GTOZ dnia 10 marca 1911 roku, zob. „Miesięcznik GTOZ” 1911, nr 3, s. 38-39. 
cudu, Po drodze) oraz teksty pisane prozą (Z łąk duszy, Wiosna idzie, Echa z ptaszęcego świata, Po wakacjach, $W$ wigilijny wieczór) publikowane wcześniej na łamach „Miesięcznika GTOZ”.

Wydawnictwo spotkało się z pozytywnym odbiorem, czego przykładem może być recenzja zamieszczona w „Słowie Polskim” 21 sierpnia 1911 roku. Jej autor podkreślał, że znalazł w utworach Mazurkówny ,jakieś dawno zamarłe echa, zatracone na rozstajach życia. [...] czar niewysławionej miłości do tworów bożych"”. Jego zdaniem

Mazurkówna wiąże potężne girlandy adoracji w hymny i śpiewa na cześć przyrody; idzie od jej słów świeżość jutrzniana, powiew słońca roziskrzony takim ciepłem, że najbardziej zimne dusze, czytając te słowa, muszą odczuć ogrom owej nadmiłości, jaką ona obdarza świat. A posiada moc opowiadania stylem barwnym, potoczystym, tak, że czytając, widzi się opisane lasy, łąki, nie pastelowym tonem, ale barwą silną i ponętną ${ }^{8}$.

Inspiracją dla Mazurkówny były letnie wycieczki po okolicach Lwowa, które były okazją do obserwacji przyrody. Swoje spostrzeżenia przelewała na papier. $\mathrm{W}$ ten sposób powstawały wiersze oraz teksty pisane prozą. We wszystkich czuło się lekkie pióro, wrażliwość, umiejętność operowania słowem i malowania obrazów, których bohaterami były przede wszystkim zwierzęta. Autorka namawiała do uważnego obserwowania tego, co wokół, patrzenia i uczenia się od natury, bo ,tyle w tym świecie zwierząt i ptaków nieocenionego przykładu dla ludzi - tyle żywej nauki, wdrążającej się na zawsze w pamięć — tyle ożywczej, błogosławionej rosy dla duszy, wyschłej w powszedniości szarych, jednostajnych dni troski i starań wyłącznie osobistych"9.

Inna wartościowa publikacja Mazurkówny to Tematy do odczytów w sprawie ochrony zwierząt wydana we Lwowie w 1914 roku nakładem Galicyjskiego Towarzystwa Ochrony Zwierząt w drukarni Piller-Neumanna ${ }^{10}$.

Mazurkówna była sekretarką Galicyjskiego Towarzystwa Ochrony Zwierząt. Założone w 1876 roku GTOZ miało na celu ochronę wszystkich gatunków zwierząt, których utrzymanie i rozmnażanie nakazywały ówczesne ustawy państwowe i krajowe, względy gospodarcze oraz naukowe ${ }^{11}$. Statut Towarzystwa z 1908 roku — poza ochroną wszystkich gatunków zwierząt oraz powstrzymaniem się od ,wszelkiej dzikości w obchodzeniu się ze zwierzętami [...] i nieludzkiego postępowania przy ich zabijaniu"12 — jako

7 Cyt. za: Miłuj przyrodę, „Miesięcznik GTOZ” 1911, nr 9 i 10, s. 115.

8 Ibidem, s. 116.

9 M. Mazurkówna, Z letnich wycieczek, „Dla Młodszych. Dodatek do Miesięcznika Galic. Tow. Ochr. Zwierząt” 1910, nr 6, s. 42-45.

$10 \mathrm{MN}, \mathrm{A} .2 / 38$, k. 100-144.

11 Ustawa Galicyjskiego Towarzystwa Ochrony Zwierząt zatwierdzona rozporządzeniem Wysokiego c.k. Namiestnictwa z 12 lutego 1876 r., Lwów 1876.

12 Statut Galicyjskiego Towarzystwa Ochrony Zwierząt, Przemyśl 1908, s. 1.

Wrocławskie Studia Wschodnie 24, 2020

(C) for this edition by CNS 
cel najwyższy wskazywał „rozbudzenie i utrzymywanie uczucia ludzkości, rozwijanie zmysłu dla przyrody i rozszerzania rozumnych pojęć o stosunku człowieka do niej, szczególnie w niższych warstwach ludności [...]"13. Duży nacisk położono na sprecyzowanie form działania towarzystwa. Przede wszystkim dawanie dobrego przykładu przez członków, uświadamianie społeczeństwa o potrzebie ochrony zwierząt, upowszechnianie wiedzy na temat podstaw prawnych w tym zakresie. Towarzystwo używało pieczęci z napisem polskim i ruskim ${ }^{14}$. W statucie sprecyzowano prawa i obowiązki członków. Każdy mógł uczestniczyć, z głosem doradczym, w posiedzeniu wydziału, który zarządzał sprawami towarzystwa. W skład wydziału wchodzili: prezes, dwaj jego zastępcy, sekretarz, zastępca sekretarza, skarbnik, pięcioro wydziałowych i pięcioro zastępców. Co warte odnotowania, w statucie zapisano: „między członkami wydziału mogą być także i panie”15. Najwyższą władzą było walne zgromadzenie. Odbywało się na początku każdego roku kalendarzowego we Lwowie. Uczestniczący w posiedzeniu członkowie wybierali wydział GTOZ, przyjmowali sprawozdanie z czynności wydziału, wyznaczali plany dalszego rozwoju towarzystwa. Założycielem i pierwszym prezesem był ksiądz Eugeniusz Janota, przyrodnik, taternik, obrońca praw zwierząt ${ }^{16}$.

Liczebność członków towarzystwa sięgała 400 osób. Siedzibą GTOZ był Lwów, filie funkcjonowały w Rzeszowie, Nowym Sączu, Kałuszu, Gorlicach, Kołomyi, Jaśle, Samborze, Krośnie, Drohobyczu i Stanisławowie.

Płaszczyzną popularyzacji wiedzy było czasopismo wydawane przez GTOZ - „Miesięcznik Galicyjskiego Towarzystwa Ochrony Zwierząt”17. W latach 1876-1892 wydawcami byli Eugeniusz Janota i Teofil Ciesielski ${ }^{18}$. Obowiązki redaktorów pełnili kolejno: Teofil Ciesielski (w latach 18761883), Feliks Lewandowski (1883-1893), Józef Limbach (1893-1918), a po roku 1918 Józef Białynia Chołodecki ${ }^{19}$.

13 Ibidem.

14 Ibidem, s. 4.

15 Ibidem, s. 6.

16 Eugeniusz Janota, „Tygodnik Ilustrowany” 1879, nr 181, s. 369-370; C. Lechicki, Janota Eugeniusz, PSB 10, 1962-1964, s. 552-553.

17 O czasopiśmie tym wspominał Jerzy Pawłowski, sugerując, że w okresie zaborów nie było na ziemiach polskich zbyt wielu stowarzyszeń zoologicznych i czasopism o takim charakterze. A te nieliczne były sporadyczne, lokalne i o krótkotrwałym działaniu. Do takich czasopism zaliczył właśnie „Miesięcznik Galicyjskiego Towarzystwa Ochrony Zwierząt”; J. Pawłowski, Periodyki okresu zaborów jako źródło do historii zoologii w Polsce, „Analecta” 2005, nr 14/1-2 (27-28), s. 129-130. O czasopiśmie zob. O. Vey, ,Miesięcznik Galicyjskiego Towarzystwa Ochrony Zwierzat" (L'viv, 1876-1915 rr.) yak dzherelo do istoriyi vynyknennya i rozvytku pryrodookhoronnoho rukhu $v$ Halychyni, ,Zbirnyk prats' Naukovo-doslidnoho instytu presoznavstva" 2014, nr 4, s. 181-190.

18 S. Krzemieniewski, Ciesielski Teofil, PSB 4, 1938, s. 60-61.

19 K. Lewicki, Chołodecki Białynia Józef, PSB 3, 1937, s. 404-405. 
Warto w tym miejscu poświęcić nieco uwagi tej postaci, bo losy Mazurkówny i Chołodeckiego były z sobą mocno związane. Biografowie Józefa Białyni Chołodeckiego eksponują głównie jego inicjatywy mające na celu upamiętnianie bohaterskich postaw Polaków, natomiast brakuje obszerniejszego omówienia działań proekologicznych. Paweł Sierżęga, autor tekstu Józefa Białyni Chołodeckiego portret własny, wspomina jedynie, że jego bohater był członkiem GTOZ oraz redaktorem „Miesięcznika GTOZ”20. Obszerniej działalność Chołodeckiego omawia Aldona Chlewicka, ukazując różne aspekty jego bogatego życiorysu ${ }^{21}$. Wiadomo, że jako miłośnik przyrody był głęboko poruszony losem zwierząt. Aktywnie zaangażował się w działalność GTOZ, pełnił w nim funkcję prezesa, był też redaktorem „Miesięcznika” wydawanego przez towarzystwo. Na jego łamach oraz w obszerniejszych opracowaniach pisał o wymarłych gatunkach zwierząt ${ }^{22}$, przybliżał czytelnikom zagadnienia ochrony przyrody, zwracał uwagę na zagrożenie wścieklizną. Działał też aktywnie na rzecz ochrony przyrody wśród młodzieży, wygłaszał prelekcje dla członków kółek przyrodniczych. Był przeciwny zabijaniu zwierząt w celu produkcji futer, wzywał kobiety, by pozbyły się futer i ozdób z piór, „tego symbolu mordowania, wypleniania niewinnych, a użytecznych stworzeń"23.

W corocznych sprawozdaniach z działalności towarzystwa zamieszczanych na łamach jego organu prasowego wielokrotnie pojawiały się pochwały pod adresem Marii Mazurkówny. Jej ofiarną pracę doceniali prezesi Adolf Mossil oraz Józef Białynia Chołodecki. Dowodem uznania było nadanie jej w roku 1912 tytułu honorowego członka towarzystwa ${ }^{24}$.

W sprawozdaniu z Walnego Zgromadzenia GTOZ z 16 kwietnia 1914 roku znalazły się podziękowania pod adresem — jak podkreślano — nie-

20 P. Sierżęga, Józefa Białyni Chołodeckiego portret własny, [w:] Wielokulturowe środowisko historyczne Lwowa w XIX i XX w., t. 1, red. J. Maternicki, Rzeszów 2004, s. 214, 221.

21 A. Chlewicka, Józef Biatynia Chołodecki-lwowski gawędziarz, [w:] Rola książki wintegracji ziem polskich w XIX w., red. B. Kosmanowa, Bydgoszcz 2000, s. 135-144.

22 Zob. J. Ch., Zwierzęta przedpotopowe, Lwów 1924.

23 J. Ch., Lwów w czasie okupacji rosyjskiej (3 września 1914 - 22 czerwca 1915). Z własnych przeżyć i spostrzeżeń, Lwów 1930, s. 27.

24 Walne zgromadzenie G.T.O.Z., „Miesięcznik GTOZ” 1912, nr 5 i 6, s. 43. Oprócz Mazurkówny tytuł ten otrzymali: Józef Białynia Chołodecki (Lwów), Florentyna Cieńska (Jabłonów), dr Teofil Ciesielski (Lwów), Ernest Domiczek (Stanisławów), Ludwik Eiselt (Stanisławów), dr Artur Holland de Grunddenfels (Wiedeń), hr. Jadwiga Kalinowska (Żółkiew), Stanisław Królikowski (Lwów), Władysław Kłaczkowski (Lwów), dr Józef Limbach (Lwów), Aleksander Maresch (Lwów), Adolf Mossil (Lwów), Józef Neumann (Lwów), F. Pławicki (Lwów), Maria Popławska (Krościenko), dr Józef Reinländer (Lwów), Mikołaj Rybowski (Lwów), H. Treter (Lwów), Teresa Witowska (Kraków). Tam też zamieszczono wykaz członków zwyczajnych: instytucji oraz osób. Wśród nich była na przykład Zofia Romanowiczówna, weteranka powstania styczniowego, nauczycielka i działaczka społeczne, hrabia Jerzy Szembek, dr Tadeusz Rutowski, hrabia Zdzisław Tarnowski, malarz Juliusz Kossak. 
strudzonej sekretarki Marii Mazurkówny, od lat pełniącej tę funkcję, która zajmowała się sprawami biurowo-kasowymi, a ponadto współredagowaniem, korektą „Miesięcznika” i jego dystrybucją ${ }^{25}$.

W sprawozdaniach sporządzanych przez sekretarkę odnaleźć można wiele informacji na temat działań podejmowanych przez Towarzystwo. W roku 1914 zwracano uwagę na zdobywanie zwolenników wśród ludności wiejskiej i to nie tylko w Galicji. Szeroki był zasięg oddziaływania „Miesięcznika”, skoro interesowali się nim na przykład mieszkańcy Śląska — zarówno członkowie czytelni ludowych, jak i osoby prywatne zwracały się z prośbą o przesłanie im archiwalnych numerów czasopisma.

Mazurkówna chętnie sięgała po pióro, by relacjonować wydarzenia związane z działaniami ekologicznymi. W ciekawy sposób opisała Muzeum Przyrodnicze im. Dzieduszyckich we Lwowie. Jego twórcom — jak pisała — przyświecał cel ,zachowania dla oczu duszy i umysłu potomnych, w nieżywych chociaż okazach, tego wspaniałego bogactwa fauny ojczystej coraz bardziej znikającej z powierzchni ziemi naszej, głównie z powodu trzebienia borów i lasów, oraz przez nierozważne niszczenie i wybijanie zwierząt [...]"26. Z wrażliwością typową dla poetów scharakteryzowała eksponaty, zwracając uwagę na różnorodność prezentowanych okazów oraz dydaktyczny charakter zbiorów. Była przekonana, że uważne oglądanie wystaw będzie miało wielki wpływ na postawy zwiedzających, jej zdaniem „,widzieć coś i poznać, to znaczy odczuć, zrozumieć, ukochać" ${ }^{27}$. Takie postrzeganie muzeum i jego roli w edukacji jest ponadczasowe i w niezmienionej formule funkcjonuje we współczesnym świecie. Tak więc poglądy Mazurkówny oparły się presji czasu i nic nie straciły ze swej aktualności.

Ciekawe spostrzeżenia zawarła też w sprawozdaniu z wystawy rybackiej zorganizowanej w październiku 1912 roku we Lwowie. Przede wszystkim zauważyła, że na wystawie pokazano tylko ryby sztucznie wyhodowane, gdy tymczasem powinny — zdaniem Mazurkówny — znaleźć się tam też ryby żyjące w rzekach, „,będące tam przepięknem, naturalnem, a obfitem bogactwem kryształowych wód naszych"28. Nie tylko podziwianie okazów było jej zamiarem. Wskazała na zmniejszenie się populacji raków, co argumentowała następująco: „Spekulanci handlarze, trudniący się od wielu lat zbyt dużą wysyłką naszych raków za granicę, dbają wyłącznie o zysk, ustawą należycie nie hamowani, nie przestrzegający czasu ochronnego raków, niszczący bezmyślnie ich samice, zachłanną polityką ową wytępili je dziś u nas prawie ze

25 Walne Zgromadzenie G.T.O.Z., „Miesięcznik GTOZ” 1914, nr 3-4, s. 31.

26 M. Mazurkówna, Przyrodnicze muzeum, „Miesięcznik GTOZ” 1910, nr 3, s. 18.

27 Ibidem, s. 20.

28 M. Mazurkówna, Wystawa rybacka we Lwowie, „Miesięcznik GTOZ” 1912, nr 11-12, s. 96.

Wrocławskie Studia Wschodnie 24, 2020

(C) for this edition by CNS 
szczętem"29. Zdaniem Mazurkówny należało na wystawie — w celach edukacyjnych - pokazać sposoby transportowania, zabijania i sprawiania ryb, bo wciąż społeczeństwu brakuje elementarnej wiedzy w tym zakresie. Choć na wystawie było dużo odwiedzających, szczególnie młodzieży szkolnej, to zdaniem Mazurkówny zdecydowanie zbyt skromnie ją reklamowano.

Przedmiotem troski Towarzystwa, ale też osobiście Mazurkówny, był los różnych zwierząt. Dała temu dowód, pisząc teksty pełne nawoływań do właściwego traktowania na przykład koni i dbania o nie. Przykładem jest artykuł Parę słów na czasie ${ }^{30}$. Sprawą koni udało się zainteresować „dyrektora weterynarii miejskiej p. Aleksandra Gottlieba, który ogląda każdego zakwestionowanego przez posterunki policyjne konia" ${ }^{31}$. Sekretarka Towarzystwa zabrała też głos w sprawie niewłaściwego traktowania koni na budowach, sugerując, że „nie ma może drugiego większego miasta w cywilizowanej Europie, w którym by tak bez litości katowano konie na placach budowy domów, jak to ma miejsce we Lwowie"32. Na posiedzeniu wydziału GTOZ 29 listopada 1912 roku przedstawiła problem złego traktowania starych, ślepych i okaleczonych koni, które zmuszane były biciem do ciągnięcia ciężkich beczkowozów z ropą. „Bezprzykładnym zdziczeniem” nazwała zachowanie woźnicy, który „grubym kijem bił konie w same oczy, potem chwycił łeb konia i wywijał nim młynka, w końcu zaś, gdy ręce go zbolały, chwycił zębami za nozdrza nieszczęśliwego zwierzęcia, gryzł go i szarpał, równocześnie butami i obcasami raniąc koniowi kopyta"33. Dzięki interwencji Towarzystwa sprawa trafiła do starostwa w Drohobyczu. Wcześniej zgłoszono 16 podobnych spraw do policji, 8 do magistratu, a kolejne 10 do innych władz ${ }^{34}$.

Mazurkówna dostrzegała potrzebę zakupu wozu ratunkowego dla zwierząt oraz stworzenia przytuliska dla zwierząt starych i okaleczonych. Zwracała uwagę na los niedźwiedzi trzymanych w lwowskim parku im. Kilińskiego. Zwierzęta były źle karmione (jeden bochenek chleba dziennie na dwa niedźwiedzie), kaleczyły się o wystające gwoździe. Towarzystwo wystąpiło do magistratu Lwowa o usunięcie zwierząt z parku. Policji donoszono o dręczeniu zwierząt domowych, maltretowaniu koni. W licznych przypadkach Mazurkówna interweniowała osobiście ${ }^{35}$.

29 Ibidem, s. 97.

30 M. Mazurkówna, Parę słów na czasie, „Dla Młodszych. Dodatek do Miesięcznika GTOZ” 1910, nr 9, s. 66-69.

31 Walne zgromadzenie G.T.O.Z, „Miesięcznik GTOZ” 1912, nr 5 i 6, s. 40.

32 M Mazurkówna, W sprawie katowania koni na placach budowy, „Miesięcznik GTOZ” 1908, nr 8, s. 127.

33 Posiedzenie wydziału G.T.O.Z, „Miesięcznik GTOZ”, 1912, nr 11-12, s. 102.

34 Walne zgromadzenie G.T.O.Z, „Miesięcznik GTOZ” 1912, nr 5 i 6, s. 39.

35 Posiedzenie Wydziatu G.T.O.Z. w dniu 9 grudnia 1910, „Miesięcznik GTOZ” 1910, nr 12, s. 182. 
Niepokoił ją los zwierząt wykorzystywanych do badań naukowych w instytucie medycznym przy ulicy Piekarskiej, a w szczególności niewłaściwe warunki ich przetrzymywania oraz niehumanitarne zadawanie śmierci ${ }^{36}$. Jej działania zaowocowały podjęciem przez GTOZ decyzji o wystosowaniu do rektora Uniwersytetu Lwowskiego prośby o skontrolowanie tej placówki.

Apelowała też Mazurkówna o poprawę losu bezpańskich psów, choć rozumiała potrzebę usuwania ich z miast. W tej kwestii była zdania, że należy zorganizować instytucję rakarza ${ }^{37}$. Interesowała ją sprawa gołębi pocztowych ${ }^{38}$, przybliżała czytelnikom sprawy obchodzenia się ze zwierzętami w różnych krajach $^{39}$. Zajmowały ją też relacje panujące wśród zwierząt, a swoje spostrzeżenia prezentowała czytelnikom „Miesięcznika”40.

Jednym z priorytetów Towarzystwa było zakładanie w szkołach kółek przyrodniczych. Inicjatywa ta zyskała poparcie dyrektora Rady Szkolnej Krajowej dr. Ignacego Dembowskiego, Rady Szkolnej Okręgowej m. Lwowa i Towarzystwa Pedagogicznego. Członkowie Wydziału GTOZ spotkali się w czerwcu 1911 roku z nauczycielami lwowskich szkół średnich. Podjęto uchwałę o zakładaniu kółek przyrodniczych w celu rozbudzania zamiłowania do przyrody i zachęcania młodzieży do ochrony i opieki nad fauną i florą. Wybrana wówczas komisja, w składzie: Adolf Mossil, Maria Mazurkówna, Józef Białynia Chołodecki i Ludwik Koerber, opracowała wzór statutu kółek, który rozesłano do szkół na terenie kraju. Zwrócono się też do Rady Szkolnej Okręgowej m. Lwowa z propozycją przeprowadzenia cyklu wykładów na temat opieki nad zwierzętami w szkołach wydziałowych i ludowych ${ }^{41}$.

$\mathrm{Na}$ spotkaniu w auli Gimnazjum im. Franciszka Józefa Mazurkówna wygłosiła referat, w którym przypomniała rozwój idei ochrony zwierząt od początku XIX wieku. Podkreśliła, że inteligentne i myślące społeczeństwa są zobligowane do krzewienia i popierania koncepcji opieki nad zwierzętami. Ważne zadania mają do spełnienia zarówno władze, jak i organizacje społeczne. Nie wystarczy jednak — zdaniem Mazurkówny — wydanie

36 M. Mazurkówna, Wiwisekcja we Lwowie, „Miesięcznik GTOZ” 1912, nr 7 i 8, s. 63-65.

37 M. Mazurkówna, W sprawie zorganizowania służby rakarzy, „Miesięcznik GTOZ” 1909, nr 5, s. 50-53.

38 M. Mazurkówna, Słów parę o gołębiach pocztowych, „Miesięcznik GTOZ” 1908, nr 4, s. 8 .

39 M. Mazurkówna, Jak obchodzi się ze zwierzętami w Marokko, „Miesięcznik GTOZ” 1908, nr 6, s. 84-88; eadem, Walka o psy, „Miesięcznik GTOZ” 1909, nr 8, s. 124-125; eadem, Przeciw barbarzyństwu, „Miesięcznik GTOZ” 1910, nr 10, s. 151-153; eadem, Niszczenie ptaków, „Miesięcznik GTOZ” 1908, nr 3, s. 33-35.

40 M. Mazurkówna, Pedagogia w świecie zwierząt, „Miesięcznik GTOZ” 1908, nr 5, s. $69-72$.

41 Posiedzenie Wydziału G.T.O.Z z dnia 20 października 1911, „Miesięcznik GTOZ” 1911, nr 9 i 10 , s. 117-118.

Wrocławskie Studia Wschodnie 24, 2020

(C) for this edition by CNS 
stosownych przepisów. Trzeba jeszcze uszlachetniać ludzi, budzić w nich uczucia humanitarne. Za niezwykle ważne uznała autorka referatu kształtowanie serc i umysłów dzieci i młodzieży. To zadanie dla domu, kościoła i szkoły, w pedagogach upatrywało Towarzystwo - reprezentowane przez Mazurkównę - partnerów, którzy zdolni byli do „pochwycenia zbożnej sprawy w umiejętne ręce i dopomożenie w pracy i w spełnianiu zadania" 42 . Jak podkreślano, „w przejrzystym i wyczerpującym zestawieniu wykazała referentka o ile kraj nasz w tej mierze pozostaje w tyle za innymi i uzasadniła potrzebę wspólnej obywatelskiej pracy pedagogów i jedynego dotychczas $\mathrm{u}$ nas $\mathrm{w}$ kraju towarzystwa" 43 . Temat propagowania haseł ochrony przyrody podnosiła Mazurkówna wielokrotnie. Na łamach „Miesięcznika” w roku 1909 apelowała do przedstawicieli inteligencji, a w szczególności do nauczycieli: „Światła zatem, światła nauk rozumnych, jak najwięcej nieście w tę ciemnotę wspólnie z nami wy, których zadaniem i celem życia winno być spełnianie przyjętego na się, wraz z nazwą światłodawców, obowiązku"44.

W sprawozdaniu z 5 maja 1912 roku z satysfakcją odnotowano, że w ciągu roku powstało wiele szkolnych kółek przyrodniczych, a ich członkowie nadsyłali informacje o podejmowanych działaniach. Sprawozdania drukowano na łamach „Miesięcznika”. Jak podkreślała Mazurkówna, podjęta inicjatywa przyniosła widoczne korzyści: ,uczniowie nabierają zamiłowania do świata przyrody, ćwiczą się w stylistyce i terminologii, a czas wolny od nauki spędzają użytecznie" 45 . Wskazała, że drzemiącą w młodzieży gotowość do krzewienia idei ochrony przyrody musi być wspierana przez pedagogów. Przykładem takiego działania może być inicjatywa Jana Baygera, nauczyciela w lwowskim Gimnazjum im. Mickiewicza, który przygotował materiały dydaktyczne do wykładów na temat ochrony przyrody. W tych działaniach wspierał go członek GTOZ dr Michał Janik. Pomocą dla nauczycieli była też wspomniana już broszura autorstwa Marii Mazurkówny zatytułowana Miłuj przyrodę.

W zakresie ochrony przyrody GTOZ współpracowało z towarzystwami łowieckimi oraz ruchem skautów ${ }^{46}$. Najwięcej uwagi poświęcano jednak edukacji ekologicznej w szkołach. Zdaniem Mazurkówny, „ilekroć wejrzymy w działania narodów obcych na tym polu i porównamy ich prace z powo-

42 M. Mazurkówna, Referat wygłoszony 29 czerwca w auli gimn. im. Franciszka Józefa na konferencji Prezydium T. O. Z. i profesorów przyrodników, „Miesięcznik GTOZ” 1911, nr 6, s. 86.

43 Kótka młodzieży szkolnej w celu ochrony przyrody, „Miesięcznik GTZO” 1911, nr 6, s. 92.

44 M. Mazurkówna, My, a zagranica, „Miesięcznik GTOZ” 1909, nr 9, s. 131.

45 Walne zgromadzenie G.T.O.Z odbyło się w ratuszu 5 maja 1912, „Miesięcznik GTOZ” 1912, nr 5 i 6, s. 37.

46 Zob. Nasza idea a skauty, „Miesięcznik GTOZ” 1912, nr 9 i 10, s. 83-84. 
łanych do tego czynników u nas — niezmiernie smutnie przedstawia się rezultat, tak bardzo bowiem daleko pozostajemy za nimi w tyle"47. Poważne wyzwanie stanęły przed nauczycielami, a także duchowieństwem. Te dwa środowiska ,powinny zasiewać, pielęgnować i krzewić w sercach ludzi ukochanie wszystkich stworzeń bożych, współczucie dla ich cierpień i niedoli, poszanowanie ich pracy dla nas [... "48. Niestety, pedagodzy i księża nie wykazywali należytego zainteresowania tą tematyką. Podobnie jak inni ludzie, a przecież byli do tego zobligowani, bo — jak pisała Mazurkówna -

Człowiecze! Władco świata i wszechstworzeń królu,

Tyś ich pierwszym tyranem, sprawcą cierpień, bólu... 49

Galicyjskie Towarzystwo Ochrony Zwierząt podejmowało wiele inicjatyw mających na celu uwrażliwienie młodzieży na cierpienie zwierząt. W roku 1914 godny odnotowania był fakt przynależności pięciu członków Towarzystwa (Chołodecki, Koerber, Limbach, Motylewski i Schneider) do „kuratorium dla popierania przedstawien kinematograficznych naukowych i pouczających" ${ }^{\circ 0}$. Ponadto prezes Chołodecki był członkiem ,,państwowej rady przybocznej dla cenzurowania firm kinematograficznych i stoi na straży, iżby filmy, nieodpowiadające warunkom na temat nadużyć i dręczenia zwierząt nie ukazywały się na ekranach" "51. Natomiast Mazurkówna została w roku 1914 zaproszona przez księżną Elżbietę Władysławową Sapieżynę z Krasiczyna na posiedzenie koła ziemianek. Wygłosiła tam odczyt na temat ochrony zwierząt, a potem sporządziła szczegółowe sprawozdanie z tego spotkania. Zostało ono opublikowane na łamach „Miesięcznika GTOZ”52. Uwagi czytelnika nie ujdzie zapewne, że autorka podczas podróży nie tylko dostrzegała piękno przyrody, lecz także podkreślała dbałość woźnicy, wiozącego ją ze stacji kolejowej do Krasiczyna, o jego konia. Relacja Mazurkówny ma też walor historyczny, bo wymieniła w niej uczestników spotkania, wśród których byli między innymi: książę Władysław Sapieha, jego żona księżna Elżbieta oraz córki: Anna i Teresa, Jadwiga Szyszkowska (kierowniczka szkoły), ks. Dubiel, Jan Śmiałkowski (nauczyciel z Korytnik), Zofia Wróblewska, Mieczysławowie Tomżyńscy, Michał Ryż, Franciszek Brudniak, Ottokar Zelinka, Kazimierz Małecki, Maria Wójcikówna, Helena Stankiewiczówna z Zalesia, Maria Kędzierska, Genowefa Pitts, Jan Rachwał, Ludwik Kasprzyk, Michał Lemczy,

47 M. Mazurkówna, Z porównań i rozmyślań, „Miesięcznik GTOZ” 1910, nr 1, s. 1.

48 Ibidem, s. 2.

49 Motto publikacji M. Mazurkówna, Tematy do odczytów w sprawie ochrony zwierząt, Lwów 1914.

50 Walne Zgromadzenie G.T.O.Z., „Miesięcznik GTOZ” 1914, nr 3-4, s. 32.

51 Ibidem.

52 M. Mazurkówna, Dzień w Krasiczynie, „Miesięcznik GTOZ” 1914, nr 5-6, s. 46. Spotkanie i odczyt Mazurkówny odnotowano na łamach czasopisma „Rola” 1914, nr 27, s. 427.

Wrocławskie Studia Wschodnie 24, 2020

(C) for this edition by CNS 
wójt Korytnik, Michał Sabat ${ }^{53}$. Do Krasiczyna przybył wraz z Mazurkówną Józef Białynia Chołodecki. W swoim wystąpieniu podkreślał potrzebę ochrony zwierząt i pochwalił inicjatywę księżnej Sapieżyny. Podczas spotkania zawiązał się pierwszy w skali kraju oddział Towarzystwa Ochrony Zwierząt na wsi. W skład zarządu weszli: księżna Sapieżyna jako przewodnicząca, Jadwiga Szyszkowska, Jan Śmiałkowski, Piotr Kuczkowski, Michał Lemczyk, Michał Sabat i Iwan Kowal ${ }^{54}$.

Odczyt wygłoszony w Krasiczynie był jednym z wielu przygotowanych przez Mazurkównę. Jak pisała na łamach „Miesięcznika”, zachęcona przez dyrekcję szkół miasta Lwowa opracowała pakiet tematów do wygłoszenia w szkołach. Zyskały one aprobatę inspektora Michała Nowosielskiego i zostały wydane nakładem GTOZ w formie broszury ${ }^{55}$. Autorka wyrażała nadzieję, że „wielu pedagogów w kraju naszym a i miłośników przyrody, będzie korzystać z nagromadzonego tu materiału i czerpać stosowne tematy do odczytów dla dziatwy szkolnej lub osób dorosłych rozmaitego pokroju ducha i umysłu, rozmaitych warstw społecznych" ${ }^{\text {. }}$.

Mazurkówna była żywo zainteresowana wszystkim, co działo się wokół. Zwracała uwagę nawet na sprawy z pozoru błahe. Opisywała codzienne sytuacje, uwrażliwiając ludzi na los zwierząt. Czytelnicy „Miesięcznika” mogli na przykład z jej tekstu poznać niemego psa Arpaksa i Wiernusia pilnujących zakładu głuchoniemych przy ulicy Łyczakowskiej we Lwowie ${ }^{57}$. Wiele tekstów poetyckich adresowanych było do najmłodszych ${ }^{58}$. Autorka doskonale rozumiała potrzebę edukacji ekologicznej. Wybierała formę przemawiania do dzieci językiem zrozumiałym, przez poetyckie opisy przyrody. Wiersze drukowane były w wydawanym w latach 1898-1913 dodatku do „Miesięcznika GTOZ” pod tytułem „Dla Młodszych" ${ }^{\text {. }}$. Mazurkówna prowadziła tam rubrykę „Drobne wiadomości”. W dodatku „Dla Młodszych” pisali między innymi Bolesław Gustawicz, Władysław Umiński, Mikołaj Rybowski.

Mazurkówna publikowała tam wiersze i krótkie opowiadania o charakterze edukacyjnym. W tekście zatytułowanym Parę słów na czasie apelowała

53 „Miesięcznik GTOZ” 1914, nr 5-6, s. 43.

54 Ibidem, s. 46.

55 MN, A.2/38, k. 100-144.

56 M. Mazurkówna, Tematy do odczytów w sprawie ochrony zwierząt, „Miesięcznik GTOZ” 1914, nr 5-6, s. 54-55.

57 Instynkt, czy uczucie i rozum, „Miesięcznik GTOZ” 1912, nr 5 i 6, s. 19-20.

58 Twórczość Mazurkówny adresowana do najmłodszych to kolejny temat zasługujący na osobne opracowanie, bo jest to przykład edukacyjnej roli poezji w II RP.

59 Szerzej o zawartości i znaczeniu tego czasopisma R.M. Zając, Galicyjski dodatek „Dla Młodszych" (1898-1913) na tle polskich dziewiętnastowiecznych czasopism popularnonaukowych, „Ananles Uniwersitatis Paedagogicae Cracoviensis. Studia ad Bibliothecarum Scientiam Pertinentia” 23, 2015, s. 126-135.

Wrocławskie Studia Wschodnie 24, 2020

(C) for this edition by CNS 
o zwracanie uwagi na los koni, a rozważania zakończyła następującym przesłaniem: „Jakże więc ogromnego trzeba ludzkości ukochania idei naszej, jakiej słodyczy, piękna, a zarazem pożaru słów, jakiej syzyfowej mocy czynów, by dotrzeć z błogosławionym światełkiem poznania, budzącym umysły i serca tam, gdzie odwieczny dotychczas panuje mrok, rodzący krzywdę" ${ }^{60}$. W innym materiale, pod tytułem $Z$ zimowych obrazków, pisała o adresowanej do młodzieży akcji dokarmiania zimą ptaków. Przytaczała przykłady działań młodych ludzi, mając nadzieję, że będą one inspirowały czytelników ${ }^{61}$. Dydaktyczną wymowę miały wiersze Mazurkówny, które adresowała do najmłodszych czytelników, ale mogli je też wykorzystać nauczyciele podczas zajęć szkolnych i przedszkolnych.

Dostrzegając potrzebę wielokierunkowej edukacji dzieci i młodzieży, Mazurkówna kierowała uwagę na tolerancję i akceptowanie ludzkich ułomności. Na łamach „Kroniki Powszechnej” można było przeczytać jej tekst zatytułowany Potega nauki w świecie głuchoniemych ${ }^{62}$. O wrażliwości i otwartości na potrzebujących świadczyć też może relacja z otwarcia bursy przy zakładzie dla głuchoniemych wychowanków lwowskiego zakładu. Przypomniała zasługi długoletniego dyrektora zakładu Antoniego Mejbauma, który był pomysłodawcą budowy bursy oraz ofiarność ludzi dobrej woli, przede wszystkim hr. Krystyny Potockiej i Bożenny Wilkoszowej ${ }^{63}$.

Pisane przez Marię Mazurkównę teksty o tematyce ekologicznej spotkały się z szerszym odzewem. Zauważyła je Eugenia Żmijewska, redagująca czasopismo „Przyjaciel Zwierząt” i zaproponowała autorce współpracę. W liście do Mazurkówny z 6 marca 1911 roku pisała:

Miło mi powiedzieć Pani, że z wielkiem zainteresowaniem czytuję Jej piękne artykuły, umieszczane w „Miesięczniku” — i że pozwalam sobie czasem przedrukować w „Przyjacielu zwierząt”. Nie śmiem prosić Szanownej Pani o współpracownictwo bezpośrednie, gdyż nasze honorarja są nader niskie, gdyby jednak Szanowna Pani bez względu na to, dla umiłowanej przez Nią idei, chciała nas zasilić swem ciepłem i pięknem słowem, byłabym wdzięczną serdecznie $^{64}$.

Mazurkówna nie pozostała również obojętna na kwestie historyczne. W swoich tekstach często odnosiła się do przeszłości. Jubileusz Gimnazjum im. Franciszka Józefa upamiętniła w wierszu zatytułowanym Wspomnienie pótwiekowego jubileuszu Gimnazyum im. Franciszka Józefa we Lwowie ${ }^{65}$.

60 M. Mazurkówna, Parę słowa na czasie, „Dla Młodszych. Dodatek do Miesięcznika GTOZ" 1910, nr 9, s. 69.

61 M. Mazurkówna, Z zimowych obrazków, „Dla Młodszych. Dodatek do Miesięcznika GTOZ” 1910, nr 2, s. 10-12.

62 M. Mazurkówna, Potęga nauki w świecie głuchoniemych, cz. 1, „Kronika Powszechna” 1912 nr 11, s. 165-166; cz. 2, „Kronika Powszechna” 1912 nr 12, s. 180-183.

63 M. Mazurkówna, Z doliny łez..., „Kronika Powszechna” 1912, nr 44, s. 302-303.

64 Cyt. za: „Miesięcznik GTOZ” 1911, nr 3, s. 38.

65 MN, A.2/38, k. 28-29.

Wrocławskie Studia Wschodnie 24, 2020

(C) for this edition by CNS 
Spod jej pióra wyszły wiersze poświęcone polskim bohaterom. W 1913 roku, w 50. rocznicę śmierci Marcina Lelewela Borelowskiego wydano drukiem broszurę z dwoma wierszami Mazurkówny. W poległym w 1863 roku uczestniku powstania widziała wzór dla kolejnych, walczących o wolność, pokoleń, które miały „rozrywać Ojczyzny kajdany”66. W słowach wiersza zawarła też powstańczą biografię Borelowskiego, mściciela niedoli, którego charakteryzuje bezgraniczne męstwo i gotowość na śmierć.

Odsłonięcie we Lwowie w roku 1913 pomnika Franciszka Smolki zainspirowało poetkę do napisania poświęconych mu strof. Wiersze zostały wydane nakładem Komitetu w formie broszury w drukarni Piller-Neumann. Poetka podkreślała zasługi Smolki, ,wielkiego syna tej ziemi”67 , który stał się „Niezłomnym sternikiem na czele powolnej, organicznej i wytrwałej pracy narodu swego"68.

Dostrzegała też poetka potrzebę utrwalenia w formie wiersza zasług osób z jej najbliższego otoczenia. Jeden z tekstów poświęciła zmarłemu Adolfowi Mussilowi, byłemu prezesowi Galicyjskiego Towarzystwa Ochrony Zwierząt. Podkreśliła jego zasługi, pisząc, że „czcił wszystko, co jest piękne - miłował, co smutne, pokrzywdzone [...]. Niósł serce [...] zawsze bezmiarem czystych poświęceń płonące" ${ }^{\prime 69}$.

Wymowny jest wiersz Mazurkówny zatytułowany Bohaterkom! Autorka wyraziła podziw dla ofiarności polskich kobiet, które zawsze stawały — w jednym szeregu z mężami, ojcami i braćmi - do walki o ojczyznę. Nie wahały się sięgnąc po broń, w milczeniu znosiły trudy walki, a gdy trzeba było - umierały $z$ imieniem Polski na ustach.

Mazurkówna z radością odnotowała narodziny wolnej Polski:

O Polsko!

Z wiekowych lat niewoli wstałaś, aby sny

Najświętsze nasze, zmienić w szczęść radosne łzy...

W purpurze krwi zabłysłaś, jak przecudny kwiat,

By poświęceniem dzieci swoich dziwić świat! ${ }^{70}$

66 M. Mazurkówna, Marcinowi Lelewel-Borelowskiemu rękodzielnikowi-pułkownikowi wojennemu wojewodzie Podlasia w pięćdziesiąta rocznicę bohaterskiej śmierci, Lwów 1913, s. 6.

67 M. Mazurkówna, Franciszkowi Smolce w dniu odsłonięcia pomnika we Lwowie, Lwów 1913, s. 6.

68 Ibidem, s. 5. Tekst został opublikowany na łamach „Kuriera Lwowskiego Południowego" 1913, nr 562; MN, A.2/38, k. 157. Cytował go J. Białynia Chołodecki, Obchód rocznicy Unii Lubelskiej w Teatrze Lwowskim, „Poradnik teatrów i chórów włościańskich” 1913, nr 11 i 12, s. 180-181.

69 M. Mazurkówna, Siewcy zbożnego słowa - Adolfowi Mussilowi, MN, A2/38, k. 25.

70 Wiersz został zamieszczony w J. Białynia Chołodecki, Kobieta polska w obronie ojczyzny. Odczyt wygłoszony z ramienia „,Uniwersytetu Żolnierskiego” w ,Ochotniczej Legii Kobiet" we Lwowie dn. 13-go czerwca 1919 roku, Lwów 1919, s. 1. Mazurkówna była też autorką wstępu do tej publikacji.

Wrocławskie Studia Wschodnie 24, 2020

(C) for this edition by CNS 
W 1920 w „Słowie Polskim” opublikowała wiersz Ida za Toba..., którego słowa brzmiały szczególnie doniośle w wojennej rzeczywistości. Z nadzieją pisała Mazurkówna:

Idą za Tobą szeregi bratnie,

$\mathrm{Z}$ mocą tej wiary -

Że Polski będzie słowo ostatnie!

Szumią sztandary -

Ponad łez - krew -

Grzmi groźny zew,

Do broni!... ${ }^{71}$

Inny wiersz zatytułowany $W$ rocznicę znalazł się (wraz z przedmową jej autorstwa) w publikacji Seweryna Falińskiego poświęconej obrońcom Zadwórza. Przypominała w nim Mazurkówna, że ,zakwita cudny kwiat pamięci”72.

Jak wielu poetów z początku XX wieku Mazurkówna z należną czcią odnosiła się do uczestników powstania styczniowego, a przede wszystkim do zesłańców. Uczyniła ich bohaterami wiersza List z Sybiru, podkreślając, że szli „Zwyciężać odwieczne zło, wroga Ojczyzny”"73. Nie zapomniała też o polskich kobietach, które zastępowały zesłanych na Sybir mężczyzn i wciąż pamiętały. Szczególnej kobiecie, czyli matce, dedykowała poetka swój wiersz Niech ci nie będzie ich żal. Nakreśliła w nim klasyczny dla polskiej rzeczywistości obraz:

Że dzisiaj syn twój ostatni,

Odejdzie w szary huf bratni,

By spieszyć się na święty bój -

Ty go nie wstrzymuj, nie żałuj -

Uściśnij jeno - ucałuj -

I pobłogosław na znój... ${ }^{74}$

Bo przecież „syn poszedł śladem praojców”75, by spełnić swój obowiązek względem Ojczyzny. Mazurkówna również realizowała swoje powinności. Stała na straży pamięci, dbała o przyrodę i aktywnie działała na rzecz środowiska. Była postrzegana jako kobieta aktywna, zaangażowana na wielu płaszczyznach, ambitna i zainteresowana ekologią, historią i sprawami bieżącymi.

Jednak o takich jak ona zanika pamięć, bo ich dokonania nie zostały rozpowszechnione, a biografie nie trafiły do naukowych opracować. Mazurkówna

71 M. Mazurkówna, Ida za Toba..., „Słowo Polskie” 1920, nr 337; MN, A.2/38, k. 160.

72 M. Mazurkówna, W rocznice, [w:] S. Faliński, Rycerze zadwórzańscy, Lwów 1927.

73 M. Mazurkówna, List z Sybiru (r. 1863), „Przegląd Poniedziałkowy” 1913; MN, A.2/38, k. 161 .

74 M. Mazurkówna, Niech ci nie będzie ich żal..., „Słowo Polskie” 1920, nr 324; MN, A.2/38, k. 162 .

75 Ibidem.

Wrocławskie Studia Wschodnie 24, 2020

(C) for this edition by CNS 
i podobne jej działaczki pozostały w cieniu, a mimo że ich praca była istotna dla regionu czy kraju, to stały w drugim szeregu, nie dbając o rozgłos.

Biografia Mazurkówny — choć znana tylko fragmentarycznie — w połączeniu z dorobkiem literackim daje obraz kresowej aktywistki. Dzięki osobom takim jak ona rozwijał się ruch ochrony przyrody, rosła świadomość społeczeństwa w zakresie ekologii oraz świadomość historyczna. Dbałość o jej zachowanie była ważna szczególnie na początku XX wieku, gdy Polacy jeszcze funkcjonowali w realiach zaborowych, a wciąż poszukiwali drogi do odrodzenia wolnej Polski.

Po Mazurkównie zostały teksty wierszy i esejów, dziś mało znane i niecytowane już prawie wcale. To dorobek indywidualny kobiety-literatki, ale pozostał też — godny odnotowania — jej wkład w zbiorowe dzieło, jakim była działalność na rzecz ochrony zwierząt na terenie Galicji, a przede wszystkim Lwowa. Pisane przez nią sprawozdania z działalność Galicyjskiego Towarzystwa Ochrony Zwierząt są dziś cennym źródłem do badań nad rozwojem ruchu ekologicznego, a także nad życiem społecznym Lwowa przełomu XIX i XX wieku.

Można z nich czerpać też inspirację dla współczesnych działań, dla mądrej i zróżnicowanej polityki ochrony przyrody w wymiarze lokalnym. Być może tekst poświęcony działalności i twórczości Mazurkówny stanie się punktem wyjścia do stworzenia monografii Galicyjskiego Towarzystwa Ochrony Zwierząt oraz przypomnienia jego działaczy, wśród których nie brakowało aktywnych kobiet.

\section{Bibliografia}

\section{Źródła archiwalne}

Muzeum Niepodległości, Zespół A 2. Kolekcja Leopolis, sygn. 38.

\section{Źródła drukowane}

Statut Galicyjskiego Towarzystwa Ochrony Zwierząt, Przemyśl 1908.

Ustawa Galicyjskiego Towarzystwa Ochrony Zwierząt zatwierdzona rozporządzeniem Wysokiego c.k. Namiestnictwa z 12 lutego 1876 r., Lwów 1876.

\section{Prasa}

„Dla Młodszych. Dodatek do Miesięcznika Galic. Tow. Ochr. Zwierząt” 1910, nr 2, nr 6, nr 9. „Kronika Powszechna” 1912, nr 11, nr 12, nr 44.

„Miesięcznik GTOZ” 1908, nr 4, nr 5, nr 6, nr 8; 1909, nr 5, nr 6, nr 9; 1910, nr 1, nr 2, nr 3, nr 6, nr 9, nr 10, nr 12; 1911, nr 3, nr 6, nr 9 i 10, nr 11-14; 1912, nr 5 i 6, nr 8, nr 9-10, nr 11-12; 1913, nr 5-6; 1914, nr 3-4, nr 5-6. 
„Poradnik teatrów i chórów włościańskich” 1913, nr 11 i 12.

„Rola” 1914, nr 27.

„Słowo Polskie” 1920, nr 324, 337.

„Tygodnik Ilustrowany” 1879, nr 181.

\section{Publikacje}

Ch. J., Lwów w czasie okupacji rosyjskiej (3 września 1914-22 czerwca 1915). Z własnych przeżyć i spostrzeżeń, Lwów 1930.

Ch. J., Zwierzęta przedpotopowe, Lwów 1924.

Chlewicka A., Józef Białynia Chołodecki - lwowski gawędziarz, [w:] Rola ksiązki w integracji ziem polskich w XIX w., red. B. Kosmanowa, Bydgoszcz 2000.

Faliński S., Rycerze zadwórzańscy, Lwów 1927.

Mazurkówna M., Franciszkowi Smolce w dniu odstonięcia pomnika we Lwowie, Lwów 1913.

Mazurkówna M., Marcinowi Lelewel-Borelowskiemu rękodzielnikowi-pułkownikowi wojennemu wojewodzie Podlasia w pięćdziesiąta rocznicę bohaterskiej śmierci, Lwów 1913.

Mazurkówna M., Tematy do odczytów w sprawie ochrony zwierząt, Lwów 1914.

Pawłowski J., Periodyki okresu zaborów jako źródło do historii zoologii w Polsce, „Analecta” 2005, nr 14/1-2 (27-28).

Sierżęga P., Józefa Białyni Chołodeckiego portret własny, [w:] Wielokulturowe środowisko historyczne Lwowa w XIX i XX w., t. 1, red. J. Maternicki, Rzeszów 2004.

Zając R.M., Galicyjski dodatek „Dla Młodszych” (1898-1913) na tle polskich dziewiętnastowiecznych czasopism popularnonaukowych, „Ananles Uniwersitatis Paedagogicae Cracoviensis. Studia ad Bibliothecarum Scientiam Pertinentia” 23, 2015.

Вей O., „Miesięcznik Galicyjskiego Towarzystwa Ochrony Zwierząt” (Львів, 1876-1915 pp.) як джерело до історії виникнення і розвитку природоохоронного руху в Галичині, „Збірник праць Науково-дослідного інститу пресознавства” 2014, nr 4, с. 181-190 [Vey O., „Miesięcznik Galicyjskiego Towarzystwa Ochrony Zwierząt” (L'viv, 1876-1915 rr.) yak dzherelo do istoriyi vynyknennya i rozvytku pryrodookhoronnoho rukhu v Halychy$n i$, ,Zbirnyk prats' Naukovo-doslidnoho instytu presoznavstva” 2014, nr 4, s. 181-190]. 